\title{
Proceeding
}

Supplementary Issue: Rio 2016 Olympic Games Second Anniversary Special Edition. Olympic Studies Forum, 2-3 October 2018.

Federal University of Espirito Santo, (Vitória - Espírito Santo), Brazil

\section{Youth Olympic Games: Using marketing tools to analyse the reality of GCC countries beyond Agenda 2020}

\author{
LEONARDO JOSÉ MATARUNA-DOS-SANTOS ${ }^{1}$, CARLOS EUGÊNIO ZARDINI-FILHO², ASLI \\ CAZORLA MILLA ${ }^{1}$ \\ ${ }^{1}$ College of Business Administration, American University in the Emirates, Dubai, United Arab Emirates \\ 2Department of Tourism Sport and Hotel Management, Griffith Business School, Grffith University \\ Queensland, Gold Coast, Australia
}

\begin{abstract}
The Olympic Games is passing through a new phase on the planet. The sport has reformed around the world especially in the Arabic-speaking Gulf countries. The local culture, religion and natural environment are the driving forces which are shaping the behaviour of the society. Nowadays, the consumption and sharing of sports information is through the medium of the latest technology like the tools of social media. The youth belonging to the Gulf Cooperation Council (GCC) countries use sports as a medium to communicate via social media. This paper used the situational analysis to describe the challenges of six communication channels for promoting the International Olympic Committee (IOC) Agenda 2020 for the GCC countries based on the SWOT, PESTLE and CATWOE methodologies. The results showed that the geographical area has huge potential to promote high performance and values of sport for future generations of athletes using the Youth Olympic Games as a seasonal door. However, an improvement from the perspective of consumer behaviour is necessary to generate youth engagement through National Olympic Committees (NOCs) during Summer and Winter Olympic Games with a heavy focus on the challenges for the new generation through social media. The recommendation points were that bilingual youth athletes (speaking Arabic and English) should be the new voice of the Olympic Movement in the GCC countries. To achieve Agenda 2020 goals, such action can engage the GCC youth generation with the Olympic Movement, including foreigners that live

Corresponding author. AUE - COBA - Dubai Academic City, Block 6-7, 2nd floor, Office 7238-Dubai, PO Box: 503000. United Arab Emirates.

E-mail: leonardo.mataruna@aue.ae

Supplementary Issue: Rio 2016 Olympic Games Second Anniversary Special Edition. Olympic Studies Forum, 2-3 October 2018. Federal University of Espírito Santo, (Vitória - Espírito Santo), Brazil.

JOURNAL OF HUMAN SPORT \& EXERCISE ISSN 1988-5202

(c) Faculty of Education. University of Alicante

doi:10.14198/jhse.2019.14.Proc3.12
\end{abstract}


in the region and not exclusively local citizens. Keywords: Sport for development; Olympism; Social Media; National Olympic Committees; Arabic Countries; Islamic Societies.

\section{Cite this article as:}

Mataruna-Dos-Santos, L.J., Zardini-Filho, C.E., \& Cazorla, A. (2019). Youth Olympic Games: Using marketing tools to analyse the reality of GCC countries beyond Agenda 2020. Journal of Human Sport and Exercise, 14(3proc), S391-S411. doi:https://doi.org/10.14198//hse.2019.14.Proc3.12 


\section{INTRODUCTION}

The last century has observed large-scale sporting events being used as a vehicle to implement political, cultural and social chances (Strittmatter, 2016). Recently, the Youth Olympic Games (YOG) was another mega sport event created to offer more competitive opportunities to athletes and increase the hosting chances for countries around the world. The Games were proposed by the IOC at the 119th IOC Session held in April 2007 (Wong, 2011). The YOG is a sports event for young athletes to show their potential; being elaborated from a necessity of the International Olympic Committee (IOC) of reaching new consumer markets and spectators (Souza, Mataruna-Dos-Santos \& Tavares, 2019).

The Olympic Games (OG) was the basis of the YOG sporting program. In the last event held at Buenos Aires (2018), there were 32 sports (including summer and winter) (Baygoc, 2018; IOC, 2018c). However, the YOG is distinct from other events by reason of its integration of a unique Culture and Education Programme (CEP) from the IOC, touching five central themes: Olympism, Social Responsibility, Skills Development, Expression and Well-being and Healthy lifestyle (IOC, 2016).

The Olympic Agenda 2020, according to the IOC (2015) is the strategic roadmap for the future of the Olympic Movement. There are 40 recommendations that combine different targets for the IOC, safeguarding the uniqueness of the Olympic Games and strengthening sports in the society. For the youth generation, the Olympic Agenda 2020 is important because it changes the face of the games and makes it more close of the future consumers of the product called Olympic Sport. The most important recommendation is "Athletes remain at the centre of all 40 of the proposals, with the protection of the clean athletes being at the heart of the IOC's philosophy" (IOC, 2015). Other factors are extremely important for the whole movement such as:

- Changes to the candidature procedure with a new philosophy to invite potential candidate cities to present a project that fits their sporting, economic, social and environmental long-term planning needs.

- Reducing the cost for bidding by decreasing the number of presentations that are allowed and providing a significant financial contribution from the IOC.

- Move from a sport-based to an event-based programme.

- Strengthen the 6th fundamental principle of Olympism by including non-discrimination of sexual orientation in the Olympic charter.

- Launch of an Olympic channel to provide a platform for sports and athletes beyond the Olympic games period, 365 days a year.

- Adapting and further strengthening the principles of good governance and ethics to changing demands. (IOC, 2015)

Hanstad, Parent and Kristiansen (2013) demonstrated that while the Olympic games are characterised by its gigantism, the YOG was designed to be of moderate size with less than half of the size of the OG. In this way, the YOG was seen as a second-order sports event requiring a lower level of financial and infrastructure commitment (Wong, 2011). As a consequence, countries which do not have the capacity to stage an Olympics could be interested in organising a smaller international event (Hanstad, Parent and Kristiansen, 2013; Wong, 2011).

On the other hand, the authors affirm that since its first edition, YOG has clearly and constantly increased in size, being similar to the enhancing aspect of the OG (Morgan, 2018). Indeed, this phenomenon is a contradiction when taking into account the initial plan of the IOC which was basically to contain the huge 
amount of investments necessary to host the YOG (Morgan, 2018; IOC, 2015). Surely, the cost of organising the YOG has been criticised, for instance, the IOC initially suggested that the YOG should not exceed US\$30 million but Singapore's winning bid of US $\$ 75.5$ million was more than two-and-a-half times the recommended cost (Wong, 2011).

It is interesting to know that the Olympic channel broadcast the YOG free for the consumers that have a cable TV in the Gulf Cooperation Council (GCC) countries. However, for OG, FIFA World Cup, Asian Cup and other events, even if you have a cable television with monthly subscription. it is necessary to purchase an extra sports pack to watch the games and matches priced at around 150-250 US Dollars per mega-event. This strategy reduces the viewing audience and acts as a limitation for attracting new consumers.

Just like the Olympic games, the Youth Olympic games are held every four years (IOC, 2016). Likewise, the host city is elected in a secret ballot by the members of the IOC after a bidding process where applicant cities are narrowed down to candidate cities (short list) by an evaluating commission established by the IOC (Hanstad, Parent and Kristiansen, 2013). Moreover, a candidate city must achieve at least $50 \%$ of the votes to be designated the winner (Hanstad, Parent and Kristiansen, 2013). The summer and winter editions are promoted in different periods, respecting a gap of 2 interleaved years between them. The table below brings the schedule of the past and future YOG.

Table 1. YOG along the years

\begin{tabular}{|l|l|l|l|}
\hline Year & Sequence & Events & Hosting City/Country \\
\hline 2010 & \multirow{2}{*}{ I YOG } & Summer & Singapore - Singapore \\
\cline { 4 - 4 } 2012 & & Winter & Innsbruck - Austria \\
\hline 2014 & \multirow{2}{*}{ II YOG } & Summer & Nanjing - China \\
\hline 2016 & & Winter & Lillehammer - Norway \\
\hline 2018 & \multirow{2}{*}{ III YOG } & Summer & Buenos Aires - Argentina \\
\hline 2020 & & Winter & Lausanne - Switzerland \\
\hline 2022 & \multirow{2}{*}{ IV YOG } & Summer & Dakar - Senegal \\
\hline 2024 & & Winter & To be confirmed. \\
\hline
\end{tabular}

Source: Adapted from Souza, Mataruna-Dos-Santos \& Tavares, 2019; IOC, $2018 \mathrm{~b}$.

The objectives of the YOG are diverse. Nevertheless, some of them draw more attention than others, such as:

a) to bring together talented young athletes aged 15 to 18 from around the world (IOC, 2016);

b) to mitigate the escalating drop-off rates for young people involved in active sport participation (Wong, 2011);

c) the need to address the phenomenon of rising youth obesity (Wong, 2011);

d) to address both marketing and health related issues (Judge et al., 2013); and

e) to allow the expansion of host sites and host benefits for Olympic related events (Judge et al., 2013). 
Facing these objectives, a crucial point to observe is the public interest in the YOG. Wong (2011) claimed that with an increasing failure to capture young audiences through the OG broadcast, a key concern of the IOC has been to develop new games in order to boost viewer numbers and broaden the audience scope. Certainly, this was the context around the creation of the YOG. However, the YOG has been struggling with the interest of spectators. The work of Judge et al. (2013) illustrated that in countries such as the USA and South Korea, the YOG faced a very low general interest and public awareness. The same authors claimed that the low levels of public awareness negatively affected the creation of actions to consume the YOG, either at the live events or via the media.

With these audience issues, other money, publicity and legitimacy problems arise (Hanstad, Parent and Kristiansen, 2013). As a result, IOC had "to push" National Olympic Committees (NOCs) delegations and other sport organisations to participate in the YOG (Hanstad, Parent and Kristiansen, 2013). On the other side, even with clear issues, authors such as Strittmatter (2016) affirm that YOG can contribute to a positive image of national sports entities, being a tool for enhancing legitimacy rather than as an action to tackle a youth drop-out problem.

In the case of less prominent nations such as South Korea, hosting Olympic events can be can viewed as a vehicle to draw worldwide interest, positioning the country as a legitimate political player in the eyes of the international community (Judge et al., 2013). However, the goals may not be translated in audience success. Judge et al. (2013) showed that the intention to watch the games on television is significantly affected by the familiarity with YOG, public awareness and use of media for sports information while the intention to attend the games as a spectator is significantly affected by familiarity with YOG, public awareness and social network service accessibility. In this sense, the simple fact of hosting the games is not synonymous with high public interest rates.

Not only public interest is an important issue, but also others must be addressed by the authorities interested in a bid for the YOG. The literature highlights the topics that, in one way or another, may be related or have an impact on the public interest in the event. Briefly, some of them can be resumed as:

a) The event brings critics around the overtraining of young competitors, risk of injuries, and psychological pressure (Judge et al., 2013);

b) As performance pressure could be a reason for dropping out of organised sports, the bid for the YOG can be seen as contradictory for national sports entities if their goal is to increase youth participation (Strittmatter, 2016);

c) Previous research shows that Olympic events do not increase mass participation, an argument frequently used by sport politicians and sport managers to justify the hosting of Olympic events (Strittmatter, 2016);

d) Not all the National Olympic Committees see the YOG as their top priority event for young athletes; consequently, not sending their best athletes to the event (Hanstad, Parent and Kristiansen, 2013); and

e) Comparing with OG, a greater percentage of YOG organising committee operational funding is paid by the host government (Hanstad, Parent and Kristiansen, 2013).

As a whole, considering all the above mentioned issues, authorities interested in organising YOG should be aware of not only the positive aspects of the event, but also of its challenges and negative effects. Mainly, the public interest has to be observed, for instance, sport marketers cannot motivate sales without first establishing an awareness of their brand/event (Judge et al., 2013). After all, awareness is an essential metric 
as it can be a major barrier when trying to impact public consumption (Judge et al., 2013). In this way, marketing analysis and strategies must be considered during the pre-bid phase by interested countries.

The marketing perspective is a fundamental point that governments should consider for the bid of sports events such as the YOG. Strittmatter (2016) claimed that the event can be presented to the society as an opportunity or a driving force for a 10-year sporting program in a country. Furthermore, it can be understood as a way to enhance its national identity despite the high financial costs (Leng, 2014). Another opportunity, the Olympic events may be used as diplomatic tools, fostering international relationships between countries (Judge et al., 2013). As it happened in Singapore, governments can also create marketing avenues for domestic businesses in association with the YOG (Judge et al., 2013). In short, international sporting events such as the Olympics, Paralympics and FIFA World Cup have been recognized as a booster for sports marketers as well as tourism developers (Judge et al., 2013).

According to Leng (2014), the decision to bid and host a major sports event is political in nature, as in the YOG case. Then, all political consequences must be weighted out, mainly those ones related to the public interest in the event and its costs. When receiving this kind of event, a normal argument is that it can enhance national pride. However, this pride is not consistent across the different demographic groups of a country, as they may have different life experiences (Leng, 2014). As a consequence, the event might not have a positive impact on a part of the population which may only have eyes for its costs. For example, females are more likely to view the hosting of major sports events as having positive impacts on the host country and hence females are more likely to indicate a feeling of patriotism and unity as compared to males (Kim and Petrick, 2005).

Other important marketing aspect, younger audiences should not be ignored since they are reported to be an essential target market to capture for securing corporate sponsorship (Wong, 2011). In order to do so, $\mathrm{IOC}$ has been reserving places for all national committees in the qualification system for each sport, so that at least four athletes per NOC, regardless of their economic means, will be given the chance to participate in the YOG (Wong, 2011). This strategy aims at enhancing the universality of the YOG (Wong, 2011), trying to attract more youth audiences.

In line with Wong (2011), in the long-term the YOG runs the danger of becoming just another sport event in a crowded sports programme, losing its marketing appeal. Certainly, it can also affect the close link between the media and sponsors, becoming a challenge for the IOC while selling the YOG to sponsors as well (Hanstad, Parent and Kristiansen, 2013). The reality is already a concerning point. The top IOC sponsors do not have to pay extra to be included in the YOG, and none of them did more than a minimum of what they usually do at the Olympics for the event (Hanstad, Parent and Kristiansen, 2013). As a matter of fact, there is little activation by most top sponsors at YOG (Hanstad, Parent and Kristiansen, 2013). Observing this scenario, Wong (2011) suggested that to increase the appeal of the YOG for the young generation, the use of new media technologies (such as its own YouTube broadcast channel and social networking sites) are central to the IOC's effort to reach out and engage them.

Based on Parent et al. (2015),media is one of the most influential stakeholders in the development of the YOG as they provide financial resources (e.g. through purchasing the rights to broadcast the Games) and visibility for the event, its athletes and sponsors. Nonetheless, the authors also describe that from the media's standpoint, it seems that the YOG will not be seen as a world-class competition with much attention, with little coverage of it in foreign media's home countries (Hanstad, Parent and Kristiansen, 2013). The IOC is used to asking a high price from a broadcasting company for the rights to cover the Olympic Games, they 
had to beg the media to cover the YOG (Parent et al., 2015). This fact is worse, considering an increasing competition for media attention, which affects second-order global sporting events such as the YOG (Wong, 2011).

Certainly, the role of media is more than visibility and providing resources. Authors point out that the media plays an important role in promoting and changing the public's perception on healthy youth (Judge et al., 2013). The media is also concerned with awareness and the intention of attending sports events (Judge et al., 2013). Particularly about YOG, Judge et al. (2013) argued that the intention to attend it is associated with the use of media for sports information, in which college students effectively use online and offline media sources to engage in sports. The same authors analysed that without the presence of media in sports, it would be difficult to inform and spread news of a new sporting event and obtain the required attention from people, a sensitive aspect of the YOG.

In other prism, Schnitzer and Kopp (2012) confirmed that research on large-scale events started becoming popular more than 30 years ago, especially in the field of tourism and leisure, focusing on economic impacts of these events. To justify the high financial costs in hosting major sports events, politicians and sports organizations have relied on research documenting the economic benefits of hosting major sports events to convince decision makers in the government and more importantly, the general public (Wood, 2006). In comparison, there are few studies on the non-economic benefits of hosting major sports events, as they are external to the economic evaluation in the decision to host the event (Leng, 2014). As the concept of the YOG is new, there has been little attention from scholars about it (Hanstad, Parent and Kristiansen, 2013), with few studies (Leng, 2014) and limited data available on it (Hanstad, Parent and Kristiansen, 2013). Because of this context, Hanstad, Parent and Kristiansen (2013) called for more research on YOG. Nonetheless, more research around the IOC TOP sponsors and the media should be conducted through marketing lenses, particularly about their evolution, issues and impact on YOG and the IOC brand (Hanstad, Parent and Kristiansen, 2013).

As a whole, this complex matrix involving the expectations around the YOG, its issues related to costs, public interest, marketing and media must be taken into consideration by countries interested in hosting the event. Observing the necessity of more studies on YOG, this paper will provide a non-exhaustive analysis related to public interest, marketing and media aspects through specifics tools in order to raise opportunities and concerns for the GCC countries, supported by the last experiences from the Buenos Aires 2018 YOG edition.

Observing the Table 2 is possible to understand the complexity of the transition in the Olympic Cycles. According to the limits of age, it is not possible for one youth athlete to attend two editions of the YOG in the same sport, except if he/she competes in the winter and summer in different sports. Sometimes, the athletes are not sufficiently mature to attend or classify to the Olympic Games, and maybe stuck in the two years gap of the games. It is not a part of this research but it is possible to find cases of youth athletes that competed in the YOG and attended the next Summer Games, and achieved good results securing medals or important classifications in the end of the competition. 
Table 2. YOG and consumer engagement along the years

\begin{tabular}{|c|c|c|c|c|c|}
\hline $\begin{array}{l}\text { Rio } 2016 \\
\text { Summer } \\
\text { Olympic } \\
\text { Games }\end{array}$ & $\begin{array}{l}\text { PyeongChang } \\
2018 \quad \text { Winter } \\
\text { Olympic Games }\end{array}$ & $\begin{array}{l}\text { Buenos } \\
\text { Aires } 2018 \\
\text { Youth } \\
\text { Olympic } \\
\text { Summer } \\
\text { Games }\end{array}$ & $\begin{array}{l}\text { Tokyo } 2020 \\
\text { Summer } \\
\text { Olympic } \\
\text { Games }\end{array}$ & $\begin{array}{l}\text { Lausanne } 2020 \\
\text { Youth Olympic } \\
\text { Winter Games }\end{array}$ & $\begin{array}{l}\text { Beijing } 2022 \\
\text { Winter } \\
\text { Olympic } \\
\text { Games }\end{array}$ \\
\hline $\begin{array}{l}\text { Youth } \\
\text { Community is } \\
\text { spectator } \\
\text { passive (TV) or } \\
\text { active (In loco } \\
\text { or Social } \\
\text { Media) }\end{array}$ & $\begin{array}{l}\text { Youth Community } \\
\text { is spectator } \\
\text { passive (TV) or } \\
\text { active (In loco or } \\
\text { Social Media) }\end{array}$ & $\begin{array}{l}\text { Youth } \\
\text { Community is } \\
\text { part of the } \\
\text { event as } \\
\text { athlete or } \\
\text { spectator }\end{array}$ & $\begin{array}{l}\text { Transition of } \\
\text { Youth People } \\
\text { for Adult } \\
\text { Athlete, } \\
\text { Spectator or } \\
\text { Consumer }\end{array}$ & $\begin{array}{l}\text { New Youth } \\
\text { Generation, } \\
\text { because is not } \\
\text { possible one } \\
\text { athlete compete } \\
\text { two times in the } \\
\text { YOG }\end{array}$ & $\begin{array}{l}\text { Transition of } \\
\text { Youth } \\
\text { Spectator for } \\
\text { Adult Athlete, } \\
\text { Spectator or } \\
\text { Consumer }\end{array}$ \\
\hline
\end{tabular}

Source: developed by the authors.

\section{METHODOLOGY}

The design of this study is descriptive and is followed for exploratory purposes. About the descriptive element, Rubio (1999) defends that its goal is to obtain information around something that already exists, to describe and interpret the reality without any interference in it. On the other side, Babbie (2007) explains that exploratory studies are done to satisfy a researcher's curiosity and desire for better understanding. Summarising, this work uses a qualitative approach for a descriptive-exploratory case study design. It was the analysis of how they used the communication regarding youth, women and highlight contents from the National Olympic Committees (NOCs) in six different portals namely the Official Website, Instagram, Facebook, Linkedln, Twitter and YouTube. The data gathering instrument used in this study is secondary data from a documentary research. The period of analysis based on all of the publications is after the closing ceremony of the Youth Olympic Games 2018 (19 Oct 2018 until 10 April 2019).

For data analysis, the use three marketing tools was planned. In this way, the analyses were based through the following strategic instruments: SWOT, PESTLE and CATWOE. These tools are frequently used in management and business studies and are also becoming applicable in the field of sport management. The SWOT analysis is a simple but useful framework for analysing an organisation's strengths, weaknesses, opportunities and threats. It can also be used for an event management as in the case of the YOG, utilising the Agenda 2020 as a background of recommendations. It helps focus on strengths, minimise threats and take the greatest possible advantage of opportunities available. A PESTLE analysis is used to evaluate the outside factors that affect a business or an event: Political: determine how the current direction of the political parties may influence the business development and growth; Economic: examine the effects of interest rates, taxes, the stock market, consumer confidence and other economic metrics; Social: acknowledge the changes in lifestyles, advertising targets, ethics, demographics and culture; Technology: evaluate a company's current technology (is it up-to-date); Legal: anticipate any new laws and regulations that may impact operations; Environment: identify the environmental factors that should be considered. For using the CATWOE, it is necessary to understand the analysis used to explore the system or processes through highlighting the roots involved in converting the inputs into outputs. 


\section{RESULTS AND DISCUSSION}

The GCC is composed of six-nations in the Middle East region namely Bahrain, Kuwait, Oman, Qatar, Saudi Arabia and the United Arab Emirates. According to the Economist (2009), the GCC countries have eight common elements that require observation:

1. The GCC has one of the fastest-growing populations in the world. By 2020 , this population is forecast to increase by one-third to $53 \mathrm{~m}$ people. The vast majority of the population will be under 25 years of age. The rapid growth and the relative youth population present serious challenges as well as major opportunities.

2. The robust population growth together with the region's affluence and its abundant natural resources point to continued strong market demand which in turn helps to make the GCC countries attractive prospects for foreign investors. At the same time, the region's long-term economic growth will depend critically on the success of efforts to educate and employ the rapidly expanding young population.

3. Rapid population growth will remain concentrated in cities. This will put pressure on public services, infrastructure and housing in urban centres. It will also create a large pool of labour that may be difficult to absorb into the private sector, owing to the mismatches not only of skills, but also of expectations of wages and working conditions. Ongoing education reforms will help, but will not solve these mismatches within the next ten years.

4. The population will remain very young over the forecast period, in contrast to the ageing populations of the US and western Europe. The proportion of the population under 15 years of age will drop from $29 \%$ in 2008 to $24 \%$ in 2020 , but will remain substantial. The large size of the young population, which has increasing access to education, the international media and new technologies, suggests that social attitudes and norms may change fast.

5. The recent trend of more women entering the labour force is likely to continue, buttressed by increased investment in educating women for jobs, a change in social attitudes and the creation of role models for a new generation of working women. Businesses will face pressure to adapt to this trend, but will not necessarily use the same models seen in the West.

6. Based on a simple extrapolation from the trends of the past five years, nationals could become a minority of the GCC population by 2021. Under the Economist Intelligence Unit's core scenario, however, nationals are likely to remain in the majority, as net immigration slows compared to its rate during the recent oil boom. Despite the slowdown, net immigration will remain strongly positive, as the private sector remains heavily dependent on expatriate labour. The gaps of cost and of skills between nationals and expatriates will gradually narrow, but will not close within the next decade.

7. The rising expatriate population will contribute to economic growth. An expanding pool of skilled professionals from overseas will provide a diverse talent pool, which should help to stimulate further economic diversification.

8. At the same time, GCC countries will face questions about how best to manage immigration, as they face competing pressures from groups that want to protect jobs for nationals and those that want more rights for immigrants. The treatment of foreign workers will become an increasingly important aspect of foreign relations with source countries. The GCC countries are unlikely to pursue a common policy on managing immigration, given the significant differences between the countries in terms of population size and natural resource endowments (The Economist, 2009, p.2).

When we look at the GCC population, we see that the majority of the population is under 25 years old and this demographic trend is highly likely to continue to remain like that until 2025. The only region that is slightly younger than the GCC countries can be found in the African countries. Indeed, US and Europe are attracting 
young talent from other countries to fight with the ageing problems however the rates are still not comparable with Middle East. However, GCC countries have seen another demographic shift with the declining fertility rate in the recent years. Women are taking more part in the household income and economic developments causing the birth rate to decline at a slow pace. The general population and the number of men per women in the region should be considered, observed and discussed because IOC wants to promote gender equality in the Agenda 2020 (see figure 1 and 2). It is easy to find a cultural imbalance that needs to provide more opportunities for women in sports. Natality may justify a part of the mentioned reason. However, it is possible for women to have more opportunities which are observed in the different aspects of the region including education and sport.

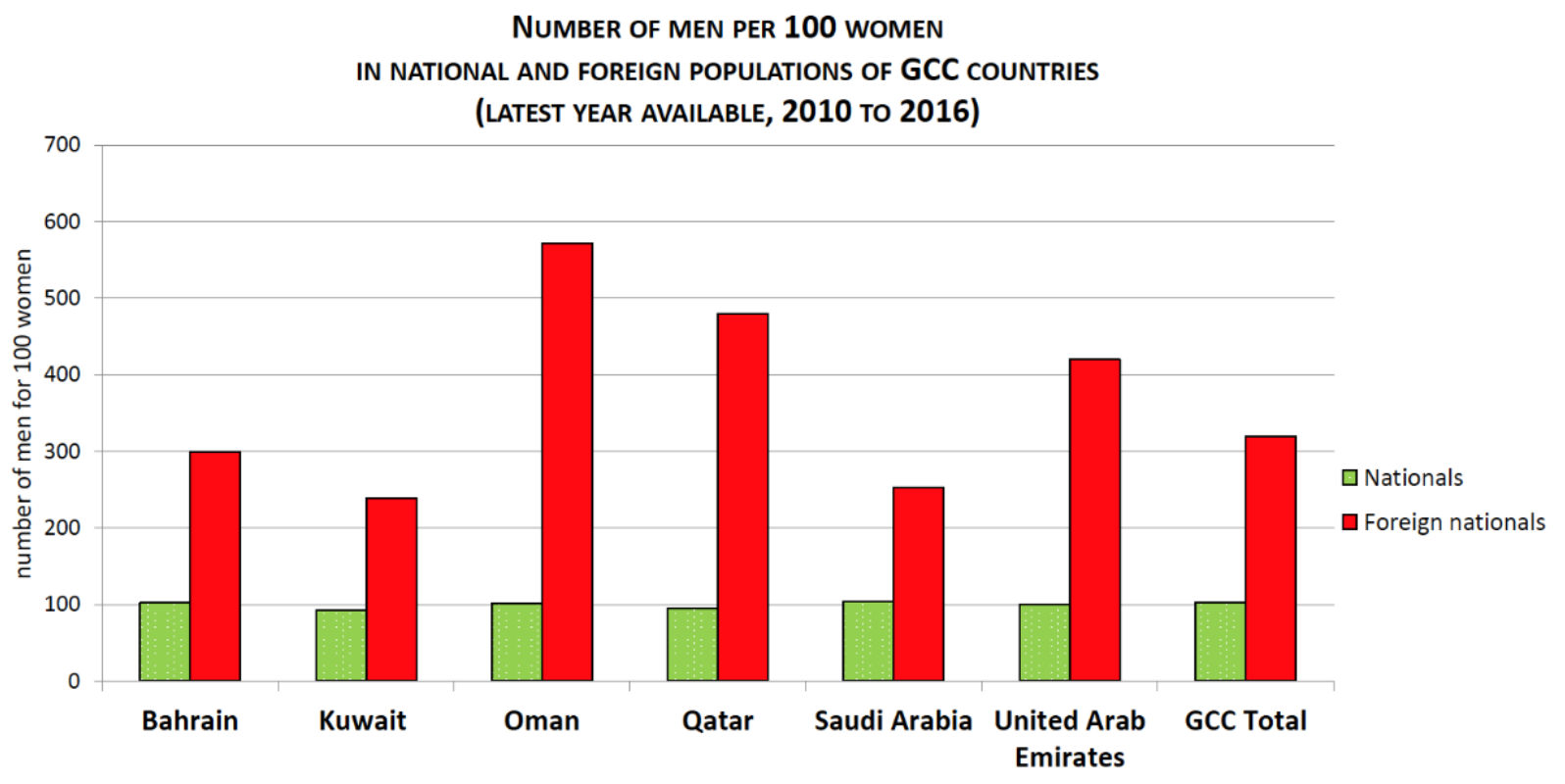

Source: Gulf Labour Market and Migration Database (20 April 2017).

Figure 1. Comparison of men per women, national and foreign in the region per country.

The change in society is accelerated and a part of change is influenced by the high number of the expats in the region. The westernisation is part of the cultural changes expected by people from abroad that live temporarily in the country.

This slowdown in the last decade is also an indicator of the number of pensioners rising than the young population, causing an increase in the old/young dependency. In many Arab countries, the marriage age is growing, even if there is little data available in the Gulf region. This trend is likely to continue as GCC nationals, both men and women, spend more time in educating themselves. GCC countries had a long baby boomers' era between the 1970s and the 1990s. As the healthcare became better, more than $25 \%$ of the GCC's population became under 25 years of age. At the same time, GCC countries have seen the increase inflow of expats aged between 15-65. 


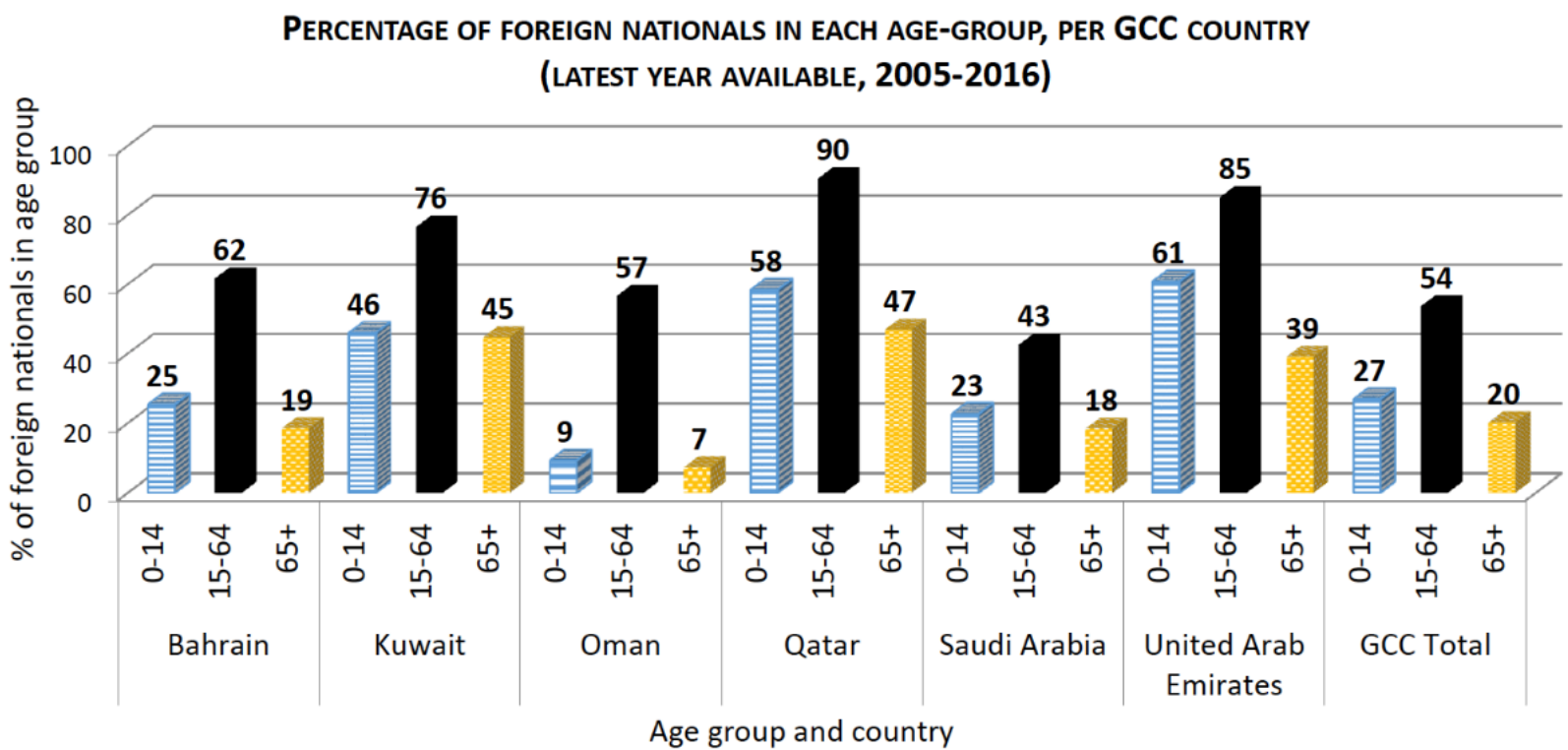

Source: Gulf Labour Market and Migration Database (20 April 2017).

Figure 2. Percentage of expats and local people per age -group and country.
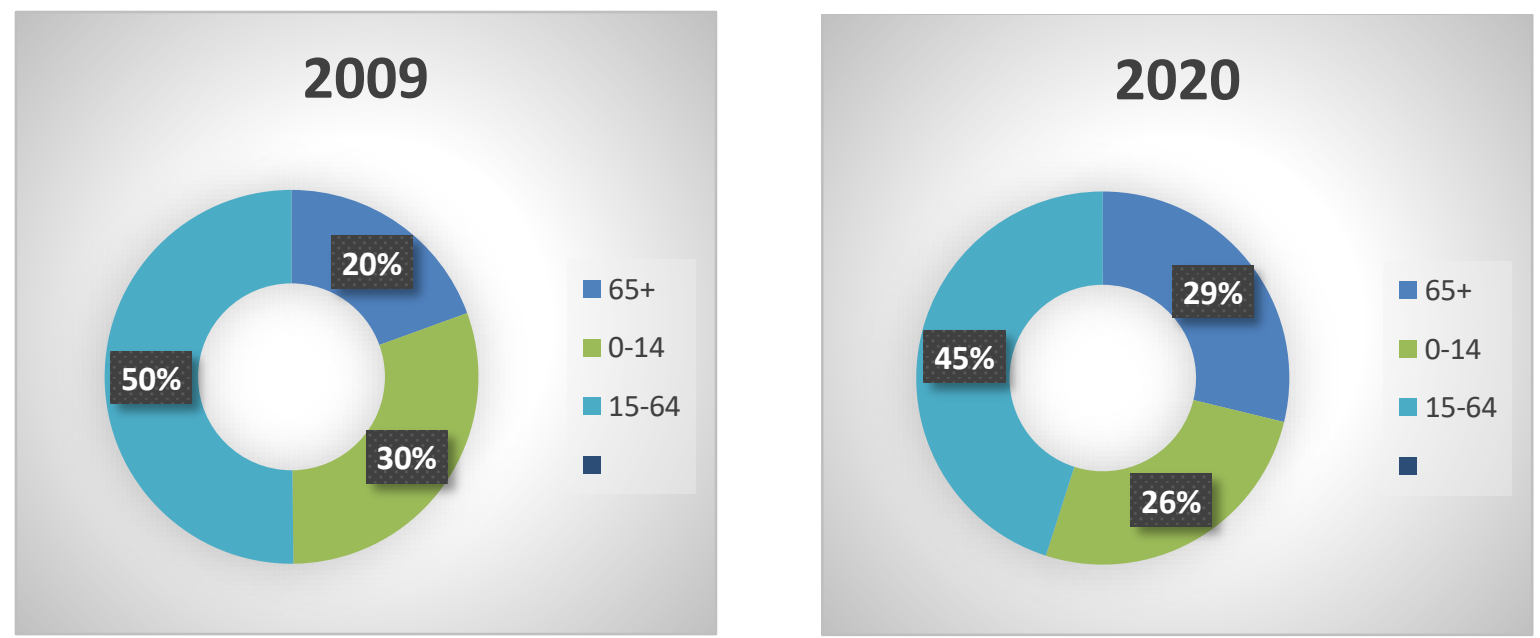

Source: Gulf Labour Market and Migration Database (20 April 2017).]

Figure 3. Youth Generation age transition from 2009-2020.

Sports must play a huge role in GCC youth because obesity and diabetic related diseases are growing day by day in the region. Countries must emphasize the importance of physical activity and the risks of lacking it in nationwide campaigns. Another trend change for GCC demographics came with the education, travelling abroad and the new technologies. The young generation who are fluent in many foreign languages are using internet as a primary communication tool. These consumer tastes are common in youth around the world. Whether it is a sociological or a market research, the overall researches done on the youth residing in GCC countries are very limited. Some surveys suggest that GCC youth are likely to be consumers of a mix of 
global and local brands. However, the youth are keen to preserve their national and Islamic identities. When it comes to consuming global media, the youth develop their own 'creative industries' with a local touch for global audiences. The young generation in the GCC can be more confident in their education, career and society, although high expectations may also be called into question if growth slows down in the next ten years.

According the Go-Gulf (2013), 88\% of the middle east online population uses social networking sites daily. The common languages used on social media are English and Arabic and all platforms for leisure and business. In this region, Facebooks users are $94 \%$, Twitter $52 \%$, Instagram $14 \%$ and Linkedln $65 \%$. The data regarding YouTube is not available but it was considered because it is an important alternative for promoting the Agenda 2020, the Olympic values and other elements corresponding to the Olympic games. Observing how the NOC's are using the social media, it is possible to notice that it is necessary to pay more attention for social media exploration. Topics such as youth sports and women sports deserve opportunities, consider the Table 3.

\section{SWOT Analysis}

Hay and Castilla (2006) explained the SWOT analysis as a one strategic planning tool used to evaluate the Strengths, Weakness, Opportunities and Threats involved in a project which should provide information to support decision- making processes. The following image presents the concept of analysis using the all recommendations of Agenda 2020 for implementation and development in the GCC countries.

\section{PESTLE Analysis}

There are environmental factors which influence business in its strategic planning. The PESTLE model gathers some of these key factors, that is: Political, Economic, Social, Technological, Legal and Environmental (Yudha \& Tjahjono, 2019; Marmol, 2015). Newton and Bristoll (2013) mentioned that the PESTLE Analysis can be used also under three perspectives: 1. Planning to launch a new product or service $\rightarrow$ YOG and Agenda 2020; 2. Exploring a new route to market $\rightarrow$ Strategies of Communication; 3. Selling into a new country or region $\rightarrow$ GCC countries, see Table 4. Certainly, each of these factors has an impact on decision-making processes; as a result, to analyse such drivers is an important task of a business analyst (Candle, Paul \& Turner, 2010). The literature also brings that it can reduce the potential threats of an organisation and open up the scope to exploit the opportunities for entering into new markets (McDonald \& Wilson, 2011). Below, figure 4 presents the factors highlighting some of the parameters.

\section{CATWOE analysis}

CATWOE model is a generic thinking concept that identifies in an organization what are the problematic areas and how solutions will impact the business and its associated people (Ali, 2019; Basden \& WoodHarper, 2006). The acronym represents Clients, Actors, Transformation, World View, Owner and Environmental Constraints (Bergvall-Kåreborn, Mirijamdotter \& Basden, 2004). Furthermore, the CATWOE analysis brings up the different stakeholder's perceptions on a common platform. However, the model has been criticised in reason of its lack of theory behind it and its lack of update; it has changed little in its form since the early 1980s (Bergvall-Kåreborn, Mirijamdotter and Basden, 2003). Figure 5 shows the elements of the model.

As mentioned by Amara (2008:72) Muslim societies are ready for adopting modern sport practices and tendencies. This represents that the 'CAT' segments of the analysis are organised to make a proper integrated fusion with the 'WOE' analysis. 
Table 3 . Social media data analysis of GCC-NOC after qualitative extraction of the social media and website

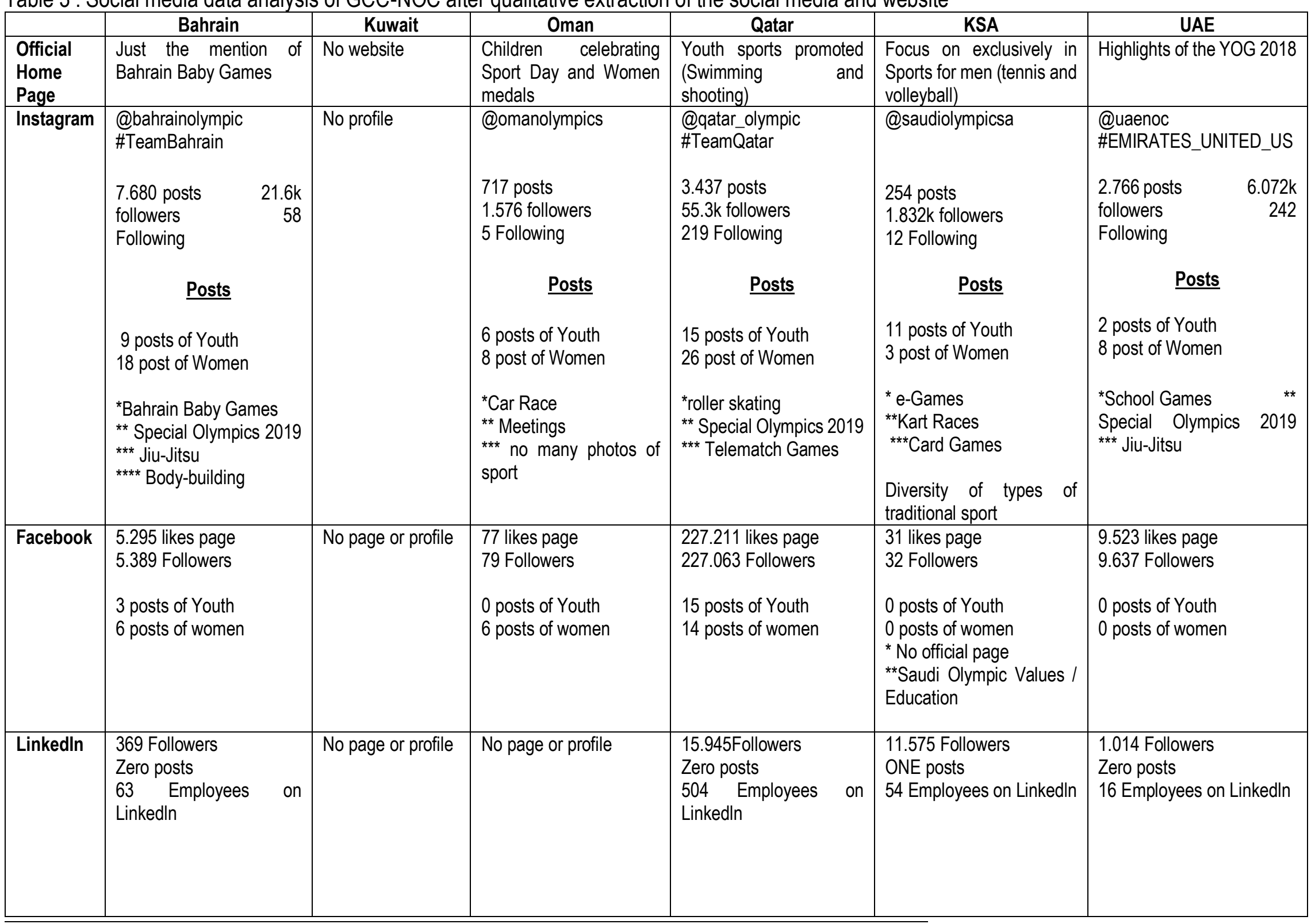

VOLUME 14 | Proc3 | 2019 | S403 


\begin{tabular}{|c|c|c|c|c|c|c|}
\hline Twitter & $\begin{array}{l}\text { @bahrainolympic since } \\
\text { Since April } 2011 \\
\text { \#bahrainolympic } \\
\\
\text { 8.371 Tweets } \\
\text { 39 Following } \\
16.6 \text { K Followers } \\
269 \text { Likes } \\
63 \text { Listed } \\
6 \text { posts of Youth } \\
12 \text { posts of women } \\
\text { * Only one proper photo } \\
\text { of athlete doing sport } \\
\text { ** posts in English and } \\
\text { Arabic }\end{array}$ & $\begin{array}{l}\text { @kuwaitolympic } \\
\text { Since September } \\
2016 \\
52 \text { Tweets } \\
12 \text { Following } \\
42 \text { Followers } \\
2 \text { Likes } \\
1 \text { Listed } \\
3 \text { posts of Youth } \\
1 \text { posts of women } \\
\text { * Baseball and } \\
\text { Shooting } \\
\text { Tournaments, and } \\
\text { Youth Athletes } \\
* * \text { Arnold Classic } \\
* * * \text { Bowling } \\
* * * \quad \text { posts in } \\
\text { English and Arabic } \\
* \star * \star A c c o u n t ~ n o t \\
\text { verified officially by } \\
\text { the twitter }\end{array}$ & 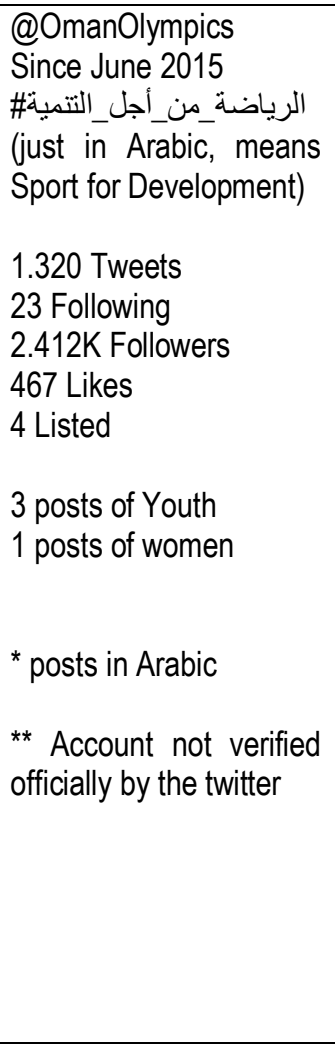 & $\begin{array}{l}\text { @qatar_olympic } \\
\text { Since February } 2011 \\
\text { \#TeamQatar } \\
\\
\text { 54.6K Tweets } \\
\text { 1.290k Following } \\
83.2 \mathrm{~K} \text { Followers } \\
\text { 3.925k Likes } \\
295 \text { Listed } \\
12 \text { posts of Youth } \\
8 \text { posts of women } \\
\text { * posts in English }\end{array}$ & $\begin{array}{l}\text { 15.8K Tweets } \\
52 \text { Following } \\
64.5 \mathrm{~K} \text { Followers } \\
1 \text { Likes } \\
280 \text { Listed } \\
2 \text { posts of Youth } \\
0 \text { posts of women } \\
\\
{ }^{*} \text { Snooker } \\
{ }^{* *} \text { Bowling } \\
{ }^{* * *} \text { e-Sport } \\
{ }^{* * * *} \text { Several publications of } \\
\text { Athletics and Judo } \\
{ }^{* * * * *} \text { posts in Arabic }\end{array}$ & $\begin{array}{l}\text { @uaenoC } \\
\text { Since March } 2011 \\
\text { \#EMIRATES_UNITED_US } \\
\text { 2.332 Tweets } \\
176 \text { Following } \\
2.9 K \text { Followers } \\
1.001 \text { likes } \\
50 \text { Listed } \\
8 \text { posts of Youth } \\
6 \text { posts of women } \\
\text { * Children carrying the UAE } \\
\text { flag in the opening } \\
\text { ceremony of Sakhalin } 2019 \\
\text { Asian Winter Games } \\
{ }^{* *} \text { UAE Sport Day } \\
\text { *** Special Olympics } \\
\text { *** posts in Arabic }\end{array}$ \\
\hline YouTube & $\begin{array}{l}26 \text { subscribers } \\
38 \text { videos } \\
\text { Youth and Women are } \\
\text { more present }\end{array}$ & No page or profile & $\begin{array}{l}2 \quad \text { profiles (Oman } \\
\text { Olympics and Oman } \\
\text { Olympic Committee) } \\
4 \text { and } 9 \text { subscribers } \\
2 \text { videos and } 13 \text { videos } \\
\text { Women and Youth are } \\
\text { more present }\end{array}$ & $\begin{array}{l}3.159 \text { subscribers } \\
\text { Women is much more } \\
\text { present }\end{array}$ & $\begin{array}{l}2 \text { subscribers } \\
2 \text { videos } \\
\text { Sportsmen }\end{array}$ & $\begin{array}{l}224 \text { subscribers } \\
204 \text { videos } \\
\text { Women and Youth are } \\
\text { more present }\end{array}$ \\
\hline
\end{tabular}

Source: developed by the authors. 


\section{Strengths}

- Evaluate bid cities by assessing key opportunities and risks (Rec .2)

- Reduce the cost of bidding (Rec.3)

- Cooperate closely with another sports event organisers (Rec.6)

- Reduce the cost and reinfore the flexibility of Olympic Games management (Rec.12)

- Maximise synergies with Olympic Movement stakeholders (Rec.13)

- Leverage the IOC USD 20 million fund to protect clean athletes (Rec.16)

- Strengthen the 6th Fundamental Principle of Olympism(Rec.14)

- Comply with basic principles of good governance (Rec 27)

- Support autonomy (Rec 28)

- Increase transparency (Rec 29)

- Address IOC membership age limit (Rec 37)

\section{Weaknesses}

- Include sustainability in all aspects of the Olympic Games (Rec.4)

- Include sustainability within the Olympic Movement's daily operations(Rec.5)

- Set a framework for the Olympic programme (Rec.9)

- Foster gender equality (Rec.11)

- Launch an Olympic Channel(Rec.19)

- Strengthen $10 \mathrm{C}$ advocacy capacity (Rec 21 )

- Spread Olympic values-based education (Rec 22)

- Evaluate the Sport for Hope programmer (Rec 24)

- Further blend sport and culture (Rec 26)

- Further involve sponsors in "Olympism in Action" programmers (Rec 33)
- Shape the bidding process as an invitation (Rec.1)

- Strengthen relationships with organisations managing sport for people with different abilities (Rec 7.)

- Forge relationships with professional leagues (Rec.8)

- Move from a sport-based to an event-based programme (Rec.10)

- Change the philosophy to protecting clean athletes(Rec.15)

- Honour clean athletes (Rec.17)

- Strengthen support to athletes (Rec.18)

- Enter into strategic partnerships(Rec.20)

- Strengthen the IOC Ethics Commission independence (Rec 30)

- Ensure compliance (Rec 31)

- Strengthen ethics (Rec 32)

- Foster dialogue with society and within the Olympic Movement (Rec 39)

- Extend access to the Olympic brand for noncommercial use (Rec 36)

- Review scope and composition of IOC commissions (Rec 40)

Source: developed by the authors.

\section{Threats}

- Engage with communities (Rec 23)

- Review Youth Olympic Games positioning (Rec 25)

- Develop a global licensing programme (Rec 34)

- Foster TOP sponsors' engagement with NOCs (Rec 35)

- Implement a targeted recruitment process (Rec 38)

Figure 4. SWOT Analysis of YOG and GCC Youth Athlete development crossed with the Olympic Agenda 2020 promotion. 
Table 4: PESTLE model factors and parameters.

\begin{tabular}{|c|c|}
\hline Politics & $\begin{array}{l}\text { - The region has its political stability except recent tension with Qatar. } \\
\text { - Political stability between GCC countries are always in favour of hosting mutual events } \\
\text { fostering relationships among nations. }\end{array}$ \\
\hline Economy & $\begin{array}{l}\text { - Region's economy is mostly stable with countries like UAE, Kuwait and Bahrain having } \\
\text { strong finances even with the latest slowdown. } \\
\text { - Expo } 2020 \text { is expected to have a positive impact not only in UAE but also in the GCC } \\
\text { region in terms of tourism and business. } \\
\text { - Non-oil economy's importance is gaining more emphasis in the region's agenda thus can } \\
\text { turn into advantage for sports and tourism industry. }\end{array}$ \\
\hline Social & $\begin{array}{l}\text { - Achieving a cohesive society and preserved identity is one of the six pillars of National } \\
\text { Agenda in line with Vision } 2021 \text { in UAE. One of the KPIs to measure such achievement is } \\
\text { the number of medals won in the Olympic and Paralympic championships in various } \\
\text { sports. (Dubai Government, 2019) } \\
\text { - Youth is influenced by Royal families and active participation of Rulers' families in sports } \\
\text { encourages society at large positively. }\end{array}$ \\
\hline Technology & $\begin{array}{l}\text { - GCC countries are keen to be the innovative leaders in the technology advancements. } \\
\text { Social media engagement is needs. } \\
\text { - Rich infrastructure capabilities are positive outcomes for sports facilities and events } \\
\text { management }\end{array}$ \\
\hline Legal & $\begin{array}{l}\text { - Each country has its own bidding and clean athlete legislation. A unified law is needed in } \\
\text { case of hosting big events. }\end{array}$ \\
\hline Environment & $\begin{array}{l}\text { - Climate is a big challenge in the region. The high temperatures do not accommodate } \\
\text { outdoor events more than } 3 \text { months in the year } \\
\text { - Snow is a no show in the region, making winter Olympics impossible to host. } \\
\text { - Wealth allows countries to invest in the develop new resources such as indoor ski resort } \\
\text { in Dubai. }\end{array}$ \\
\hline
\end{tabular}

Source: developed by the authors.

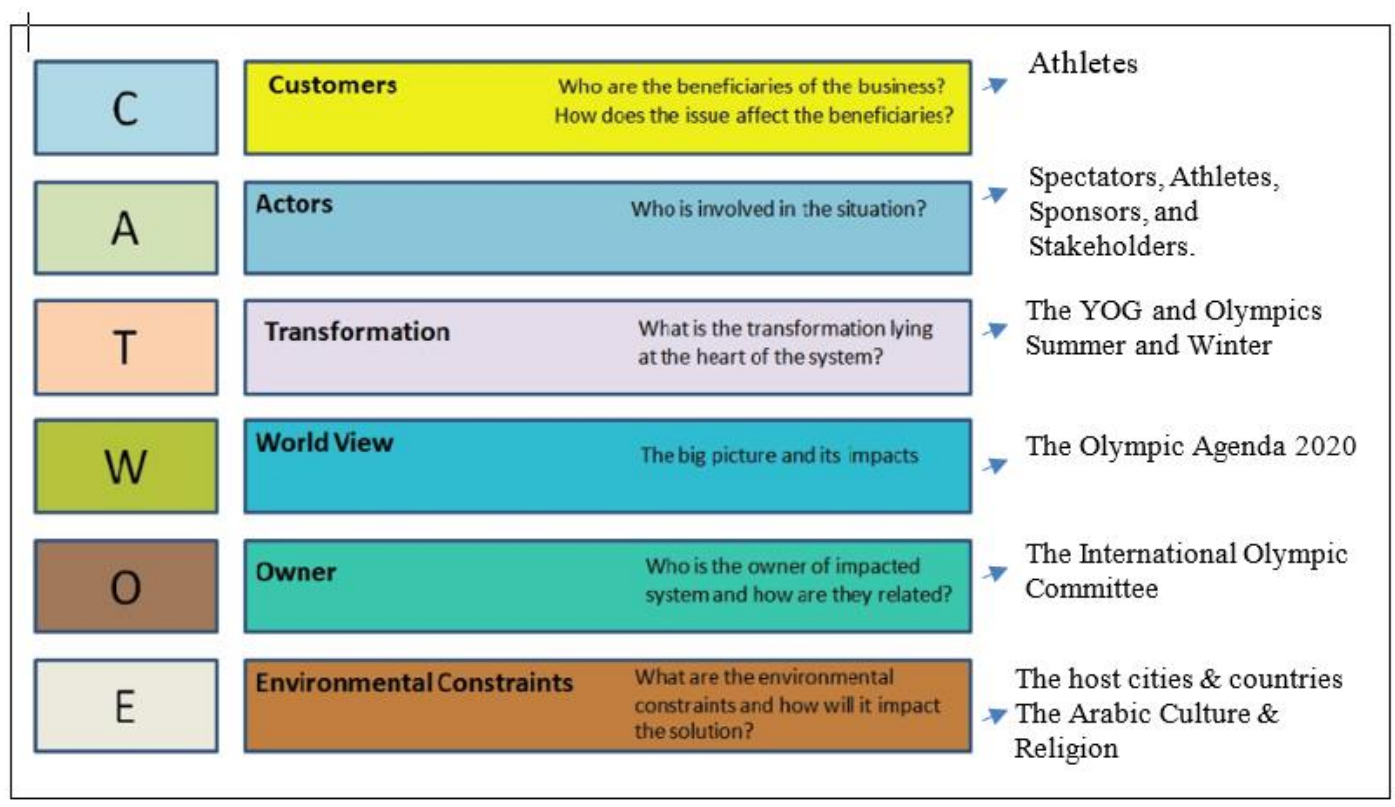

Source: Adapted from Ali (2019); Bergvall-Kåreborn, Mirjamdotter \&Basden (2003).

Figure 5. CATWOE analysis model. 


\section{CONCLUSION}

The intention to host the Youth Olympic games in UAE or other GCC countries may positively promote the sport for youth in the region in line with the Agenda 2020. Furthermore, to be a prospective candidate to host the Youth Olympic games is an easier process compared to the hosting of the summer or winter Olympic games. The Union of Arab National Olympic Committees is another partner of IOC that can handle the burgeoning opportunities for youth in sports. It is recommended that the Pan-Arab Games should create a session or a dedicated event for youth athletes. However, the obstacles for organizing the XIV edition of the 2019 Pan-Arab Games may represent a hurdle for this recommendation. The idea should be to create an exclusive event for youth in the GCC countries including participation from both local and foreign athletes which may amplify the incentives for sport promotion in the region. A salient mention of the various sports tournaments organised during the holy month of Ramadan in the Arab and GCC countries which are inclusive, attracting participation from both local and foreign youth. The organisation of such events may be used as an example for the organisation of an all-inclusive event attracting diverse participation on a large scale.

Unfortunately, the principles of diversity and inclusion are not reflected in the contents of the NOC's official social media channel due to Arabic language being primarily used in the shared posts.

From another perspective, it is also necessary to look at youth as future athletes and consequently as a future ex-athlete, when finalise their careers. Recently, a meeting organized by the IOC (2019) where 350 athletes from more than 185 countries came up with nine recommendations after the International Athletes Forum:

1. To strengthen an athlete's representation.

2. To strengthen the solidarity funding model.

3. To strengthen the direct financial support for NOC Athletes commissions.

4. To strengthen the support for career transition.

5. To strengthen the protection of clean athletes and the fight against doping.

6. To focus on an athlete's mental health.

7. Support for the Athletes' Declaration.

8. To invite athletes to be ambassadors for the Olympic movement.

9. To foster engagement and communication among the Athletes' commissions network.

We are living in the information age where social media has become a fundamental tool to enhance the communication between people, especially among the youth to an extent that it has become a part of their daily routine to engage with the virtual world. The use of social media as a tool to promote Olympic games has become more of a necessity than another mere option in this digital age.

It is evident from the analysis of the results that the social media penetration rate is very high across the GCC countries. However, a different picture is portrayed when the digital numbers and interactions of the various Olympic social media channels is taken into consideration. As evident from nature, social media is a dynamic, real-time engaging and an interactive medium of communication. This is one of the main advantages of having a strong social media presence which allows brands or organisations to interact with their audience or consumer base in real-time. The social media channels of the GCC Olympic committees are primarily used as a mass media medium resulting in a one-way communication channel rather than providing a platform for users to engage. 
The content is king when it comes to engaging with generation $Z$ audience. Social media content must be tailored according to the needs of the audience and the platform while taking into account the 80/20 rule. Organisations should make sure that $80 \%$ of their posts are of engagement nature while the other $20 \%$ are to announce latest news and important updates. Unfortunately, we did not see any informative content for the youth to be engaged and learn more about the Olympics in general.

Agenda 2020 emphasises gender equality and women empowerment in Olympics. The number of posts shared related to women are very limited in the above channels. This may provide a challenging situation when it comes to aligning the national Olympic strategy with the Agenda 2020 recommendations.

The role of physical education in the early stages of school should not be neglected as an important channel to promote the Olympic values and Olympic movement with the International Federation of Physical Education (FIEP) having a positive role in promoting and supporting such recommendations around the region.

Lastly, it was observed that the promoted sports mostly were not Olympic sports such as bowling or snooker. The focus should be on the Olympic sports so that the youth who are active on social media may be influenced and encouraged to join the Olympic Movement.

As a recommendation, other businesses and psychological models should be tested such as AttentionInterest-Desire-Action (AIDA). According to Judge et al (2013), one of the models emphasizing awareness developed over a century ago was AIDA. This approach described the process of the consumers utilising when making decisions based upon an advertising message. The mentioned concept can be applied to the YOG. Combining AIDA with other methodologies may provide interesting solutions for application of strategies in the GCC Countries. The recommendations embrace to extend the area observed to the Middle East and North Africa (MENA) region.

\section{REFERENCES}

Ali, S. (2019). The Development of Depok Civil Servant Training and Education System. International Journal of Multicultural and Multireligious Understanding (IJMMU). Jakarta International Conference on Social Sciences and Humanities (JICoSSH) Vol. 6, Special Issue 2, February 2019.

Amara, M. (2008). The Muslim World in the Global Sporting Arena. The Brown Journal of the World Affairs. Vol. XIV, issue, 2, p. 67-75.

Axon R. (2018, November 11) Snowboarding story: from outcast to Olympic Darling in 20 years. Retrieved from: https://www.usatoday.com/story/sports/winter-olympics2018/2018/02/08/snowboarding-story-outcast-olympic-darling-20-years/317370002/

Babbie, E. (2007). The Basics of Social Research. USA: Cengage Learning.

BAYOGOC (2018, November 8). Unos juegos para la historia. Retrieved from: https://www.buenosaires2018.com/the-games-that-made-history!/history/ 5bca3df2c05d00056a1ea743? Ing=es. Acesso em: 08 de novembro de 2018.

Basden, A., \& Wood-Harper, A. T. (2006). A philosophical discussion of the root definition in soft systems thinking: an enrichment of CATWOE. Systems Research and Behavioral Science, 23(1), 61-87. https://doi.org/10.1002/sres.689

Bergvall-Kåreborn, B., Mirijamdotter, A., \& Basden, A. (2004). Basic principles of SSM modeling: an examination of CATWOE from a soft perspective. Systemic Practice and Action Research, 17(2), 5573. https://doi.org/10.1023/b:spaa.0000018903.18767.18 
Bergvall-Kåreborn, B.; Mirijamdotter, A.; and Basden, A. (2003, September 2). Reflections on catwoe, a soft systems methodology technique for systems design. Proceedings of the 9th Annual CPTS Working Conference. https://doi.org/10.1023/b:spaa.0000018903.18767.18

Brittain, I.; and Mataruna-Dos-Santos, L. J. (2017). Social legacies of Olympic and Paralympic Games in East London. In: Cohen, P.; Watt, P. (2017). London 2012 and the Post-Olympics city - a hollow legacy? London: Palgrave Macmillan. https://doi.org/10.1057/978-1-137-48947-0_13

Cadle, J.; Paul, D. and Turner, P. (2010). Business Analysis Techniques: 72 essential tools for success. BCS The Chartered Institute for IT.

Darling, M. et al (2005). Learning in the Thick of It. Havard Business Review, July.

Dharmalingam, N. (2018, December 1). 10 Most Popular Business Analysis Techniques. Retrieved from: https://www.whizlabs.com/blog/best-business-analysis-techniques/ Published on: July 16, 2018.

El Patagónico (2018, November 3). La TV alemana presentó un informe sobre el excesivo gasto de dinero detrás de los JJOO. https://doi.org/10.30875/17eb8f18-es

Fredrick, M. (2016). MOST analysis sample. Retrieved from https://www.linkedin.com/pulse/mostanalysis-sample-case-coca-cola-company-mabago-fredrick

Fricke, G. (2014, November 10). Skate nas Olimpíadas? Elite se divide sobre inclusão do esporte nos Jogos. https://doi.org/10.11606/d.101.2017.tde-23112017-140406

Hansard (2005, November 3). House of Commons Debates 'London 2012 Olympic Bid'. 6 July 2005 UK Parliament.. Retrieved from: https://publications.parliament.uk/ pa/cm200506/cmhansrd/v0050706/ debtext/50706-33.html

Hanstad, D.; Parent, M., and Kristiansen, E. (2013). The Youth Olympic Games: the best of the Olympics or a poor copy?, European Sport Management Quarterly, 13 (3), 315-338. https://doi.org/10.1080/16184742.2013.782559

Hay, G.; and Castilla, G. (2006, April 3). Object-based image analysis: Strengths, weaknesses, opportunities and threats (Swot). Retrieved from http://www.isprs.org/proceedings/xxxvi/4c42/Papers/OBIA2006_Hay_Castilla.pdf

IOC - International Olympic Committee (2016). What is YOG? Retrieved from https://www.olympic.org/news/what-is-yog

IOC (2015, December 1). Agenda 2020: 20+20 Recommendations. Retrieved from: https://stillmed.olympic.org/media/Document\%20Library/OlympicOrg/Documents/Olympic-Agenda2020/Olympic-Agenda-2020-20-20Recommendations.pdf\#_ga=2.40146 402.1376710818 . 1541988836-427607152.1505938760. Acesso em: 11 de novembro de 2018.

IOC (2017, November 10). Olympic Charter. Retrieved from: https://stillmed.olympic. org/media/Document\%20Library/OlympicOrg/General/ES-Olympic-Charter.pdf\#_ga $=2.245217861 .1376710818 .1541988836-427607152.1505938760$

IOC (2018a, November 9). Freestyle skiing. Retrieved from: https://www.olympic.org/ freestyle-sking

IOC (2018b, November 10). The YOG - vision, birth and principles. Retrieved from: https://stillmed.olympic.org/media/Document\%20Library/OlympicOrg/Factsheets-ReferenceDocuments/Games/YOG/Factsheet-The-YOG-Vision-Birth-and-Principles.pdf

IOC (2018c, November 10). Youth Olympic Games. Retrieved from: https://www.olympic.org/youtholympic-games

IOC (2019, April 15). Biggest ever International Athletes' Forum ends with concrete proposals to further increase the support to athletes at all levels. Retrieved from: https://www.olympic.org/news/biggestever-international-athletes-forum-ends-with-concrete-proposals-to-further-increase-the-support-toathletes-at-all-levels 
Judge, L.; Lee, D.; Surber, K.; Bellar, D.; Petersen, J.; Ivan, E.; and Hyeon J. (2013). The Promotion and Perception of the Youth Olympic Games: A Korean Perspective. Journal of Research in Health and Physical Education, 8 (2), $12-18$.

Kim, S.; and Petrick, J. (2005). Residents' perceptions on impacts of the FIFA 2002 World Cup: The case of Seoul as a host city. Tourism Management, 26, 25-38. https://doi.org/10.1016/.tourman.2003.09.013

Kirschbaum, R. (2018, November 1). Legado de los Juegos Olímpicos de la juventude. Retrieved from: https://clar.in/2ERZYIp.Clarin

Lampathaki F.; Koussouris S.; and Psarras J. (2013, May 3). Business Process Modelling. Retrieved from X0\%3D\&tabid $=930 \&$ mid $=2218$ http://academics.epu.ntua.gr/LinkClick.aspx?fileticket=nNPcBN7bj

Leng, H.; Kuo, T.; Baysa-Pee, G.; and Tay, J. (2014). Make me proud! Singapore 2010 Youth Olympic Games and its effect on national pride of young Singaporeans. International Review for the Sociology of Sport, 49(6) 745-760. https://doi.org/10.1177/1012690212469189

MacRury, l.; and Poynter, G. (2009). London's Olympic Legacy: a "Think piece" report prepared for the OECD and Department of Communities and Local Government. London: London East Research Institute.

Marmol, T. (2015). PESTLE Analysis. E-book, 50Minutes.

Mataruna-Dos-Santos, L. J. (2013). LONRIO - Managing the knowledge transferability and social legacy from London 2012 to Rio 2016. First Report. Coventry: European Union.

Mataruna-Dos-Santos, L.J.; and Pena, B.G. (2017). Mega Events Footprints: past, present and future. Rio de Janeiro: Engenho.

Mataruna, L. (2007). Perception of Pan-Am Games Rio 2007 by specialists in Olympic Studies. In: Rodrigues, R.P; Pinto, L.M.M.; Terra, R.; DaCosta, L.P. (2008). Legados de megaeventos esportivos. Brasilia: Ministério do Esporte, 2008.

McDonald, M; and Wilson, H. (2011). Marketing plans: how to prepare them, how to use them, 7th Edition, John Wiley. https://doi.org/10.1002/9781119205876

Morgan, L. (2018, November 6). Do the Youth Olympic Games have a future? Retrieved from: https://www.insidethegames.biz/articles/1070764/do-the-youth-olympic-games-have-a-future

Newton, P.; and Bristoll, H. (2013). Pestle Analysis. Free management e-books, ISBN 978-1-62620-9985.

Parent. M.; Kristiansen, E.; Skille, E.; and Hanstad, D. (2015). The sustainability of the Youth Olympic Games: Stakeholder networks and institutional perspectives. International Review for the Sociology of Sport, 50(3) 326-348. https://doi.org/10.1177/1012690213481467

Poynter, G. (2008). Regeneração Urbana e Legado Olímpico de Londres 2012. In: Rodrigues, R.P; Pinto, L.M.M.; Terra, R.; DaCosta, L.P. (2008). Legados de Megaeventos Esportivos. Brasília: Ministério do Esporte / CONFEF.

Rubio, V. (1999). Introdução ao projeto de pesquisa científica. Petrópolis: Vozes.

Schnitzer, M.; and Kopp, M. (2012). Measuring the impacts of the Winter Youth Olympic Games 2012 the impact - stakeholder approach. Sports Med, 46 (15), 1029-1030. https://doi.org/10.1136/bjsports-2012-091700

Silva, F.C.T (2016). Estudos comparados como método de pesquisa: a escrita de uma história curriculares. Revista Brasileira de Educação. v.21, n.64, p. 209-224. https://doi.org/10.1590/s141324782016216411

Strittmatter, A. (2016). Defining a problem to fit the solution: A neo-institutional explanation for legitimising the bid for the 2016 Lillehammer winter Youth Olympic Games. International Journal of Sport Policy and Politics, 8 (3), 421-437. https://doi.org/10.1080/19406940.2016.1138990 
Souza, A.L.; Mataruna-Dos-Santos, L.J. \& Tavares, (2019). O. Os Jogos Olímpicos da Juventude: Buenos Aires, Cidade Olímpica. In: Rubio, K. (2019) p.231-246.

Turini, M.; Gomes, M.; Miragaya, A.; DaCosta, L. (2008). Jogos Olímpicos da Juventude: Um Novo Megaevento Esportivo de Sentido Educacional Focado em Valores. In: Rodrigues, R.P; Pinto, L.M.M.; Terra, R.; DaCosta, L.P.(2008) Legados de Megaeventos Esportivos. Brasília: Ministério do Esporte / CONFEF. https://doi.org/10.1590/s0101-32892014000200012

Wong, D. (2011). The Youth Olympic Games: Past, Present and Future. The International Journal of the History of Sport, 28 (13), 1831-1851. https://doi.org/10.1080/09523367.2011.594687

Wood, E. (2006). Measuring the social impacts of local authority events: A pilot study for a civic pride scale. International Journal of Nonprofit and Voluntary Sector Marketing, 11, 165-179. https://doi.org/10.1002/nvsm.21

Yudha, S.W.; and Tjahjono, B. (2019). Stakeholder Mapping and Analysis of the Renewable Energy Industry in Indonesia. Energies, 12, 602. https://doi.org/10.3390/en12040602 